\title{
Improving Teacher Competence in Making Class Action Research Through Assignment, Feed Back, and Revision Workshop
}

\author{
Rasmin Simbolon \\ Educational Technology Study Program, \\ Universitas Negeri Medan, \\ Medan 20221, Indonesia \\ rasminsimbolon02@gmail.com
}

\author{
Abdul Hasan Saragih, Julaga Situmorang \\ Educational Technology Study Program, \\ Universitas Negeri Medan, \\ Medan 20221, Indonesia \\ ahasansaragih@gmail.com; \\ profesorjulagasitumorang@gmail.com
}

\begin{abstract}
Teachers in State Junior High School 30 (SMP Negeri 30) Medan still has particularly low competence to make proposals of Class Action Research (CAR). The aim of this study is to determine the competence of teachers in making CAR. The hypothesis of this study is the competence of teachers in making CAR can be increased through the Workshop of Assignment, Feed Back, and Revision (AFR) model. CAR is done through AFR Model Workshop. The model used in this workshop is a model of Kemmis which is designed in cycle process consisted of four phases of activities, namely: planning, action, observation, and reflection. These phases keep repeating until the problem is considered resolved. The results of the data analysis in making CAR is cycle 1 was 48.05. Cycle 2 was 67.60. Cycle 3 was 82.85. The average of the increase in teacher competency in cycle 1 was $34.80 \%$. The increase in the average value of the teacher competency doing this workshop was $34.80 \%$. The implementation of Workshop AFR Model was conducted by a) explanation of the material from researchers as speakers, b) Assignment, c) Feed Back, and d) Revisions which can improve teacher competency in SMP Negeri 30 Medan in making AFR.
\end{abstract}

Keywords-Competence; Classroom Action Research; and Workshop

\section{INTRODUCTION}

Teachers today are expected to be able to increase their professionalism in the work. To achieve this the teachers should be provided with the ability of researching, particularly in Class Action Research (CAR). In this case the supervisor's roles as manager and mentor teachers are certainly very needed. Supervisors not only serve as a mentor or consultant, but also can collaboratively conduct an action research together with teachers to improve lessons.

Based on preliminary data, the results of supervision carried out by researchers to the teachers of SMP Negeri 30 Medan obtained preliminary data: $100 \%$ of teachers still have low competence to make proposals of Class Action Research. $100 \%$ of teachers have never obtained a guidance of a Class Action Research (CAR). $100 \%$ of teachers have never done a
Class Action Research (CAR). From the preliminary data results turned out that the teachers have not been able to create a Class Action Research (CAR).

In accordance with the facts of teachers of SMP Negeri 30 Medan it is then very necessary to conduct an Action Research in the school in order to improve teacher's competence in making class action research through AFR model workshop at State Junior High School 30 In Medan.

Based on the background of the problem, it could be identified that;

1. The students of SMP Negeri 30 Medan lack of cooperation in learning activities.

2. Teachers of SMP Negeri 30 Medan less engage students in learning activities in groups.

3. Teachers of SMP Negeri 30 Medan do not understand how to create a Class Action Research (CAR).

Guza [1] says that the teacher competency standard includes four main competencies: (1) pedagogical, (2) personal competence, (3) social competence, and (4) professional competence. Noticing the teacher competencies that every competence required by the teachers must have mutual relationship in order to create an optimal teacher competence. [2].

According to Sukardi in Kemmis [3], an action research is a form of research on self reflection undertaken by participants in social situations (including education) to improve the practice done by themself. [4]. Thus, it will obtain a comprehensive understanding of the practice and the situation in which the practice is carried out. There are two main things in action research, namely improvement and engagement. These will direct their action research into three areas: (1) to improve practices, (2) for professional development in the sense of improving the understanding of practitioners to practice implementation, and (3) to improve the situation where such practices are held. 
Arikunto [5] describes the CAR through a combination of three-word definition of "research" + "Action" + "Class". The meaning of each word is as follows.

Research; the activities that examine an object by using certain way and methodologies to obtain data or useful information in solving a problem. Action; a motion of activities which is done for a specific purpose. The action is conducted in class action research in a series of cycles of activity. Class; a group of students in the same time who receive the same lesson from the same teacher as well. Students who learn not only confined in a classroom alone, but also when students are conducting field trips, laboratory experiments, or studying elsewhere in the guidance and direction of the teacher. T. Sunimi [6] The main purpose of class action reasearch is to solve the real problems that occur in the classroom as well as to seek a scientific answer to why it can be solved through the action. Output or the expected result through CAR is an increase or improvement of process quality and learning outcomes which include the followings: (1) an increase or improvement of the performance of students in the school, (2) an increase or improvement of the quality of the learning process in the classroom, (3) an increase or improvement of the quality of the use of media, learning aids and other learning resources, (4) an increase or improvement of the quality of procedures and evaluation tools used to measure the process and student learning outcomes, (5) an improvement of educational problems of children in the school, (6) an increase and improvement of the quality in curriculum implementation and development of student competence in the school.

There are some principles that need to be considered by the teacher (or researcher) in the implementation of the CAR, that is, firstly, actions and observations in the research process must not interfere with or impede the main activity, for example a teacher should not come at the expense of learning activities. Secondly, the problem of the study is a problem that is quite worried about and rests on the professional responsibility of teachers. Thirdly, the data collection method which is used do not require a long time, so it likely does not interfere with the learning process. Fourthly, the methodology should be planned carefully, so that action can be formulated in a hypotheses of action which can be tested in the field. Fifthly, issues or topics that have to be selected are completely real, charming, able to be handled, and within the authority of researcher to make changes. Finally, the researcher must keep attention to the ethic and norm of research as well as the rules that are generally accepted.

According to Suprijanto [7] workshop is a meeting of people working together in small groups, usually limited to issues stemming from their own.[8]. The participation is expected to be able to produce a certain product. To implement the workshop in making CAR follows some steps, namely: (1) determining the workshop materials, (2) the researcher provides guidances and directions to make the CAR and assigns tasks to the teachers and the deadline to do it, (3) each teacher works based on directions and within the specified time, (4) if the working time runs out, the teachers are asked to demonstrate their work, (5) holding an informative question-and-answer about the work of each teacher, (6) the researcher makes an assessment of the entire work and discusses things that are special in each work, then continued to certain question and answer between the participants and the researcher.(7) the researcher makes the result of the entire research and conveys suggestions and inputs that they are considered to be necessary.

The number of participants is limited in order to obtain good results. They are summoned to the workshop with a special invitation. Due to the small groups it is possible to have an intensive study.

According to Zaini [9] the workshop is designed for teachers in the school.[10]. It is based on the consideration that the materials and strategies taught in workshops tailored to adult education. This workshop uses andragogy approach

At the stage of the initial activity, the teachers of SMP Negeri 30 Medan together with researchers began the activities by doing a trial workshop for gaining preliminary data of teacher competence in making classroom action research (CAR), identifying the problems faced by teachers and finding the solution to the problem, then jointly establishing the biggest problems experienced by teachers.

At the planning stage, the teachers of SMPN 30 Medan were guided by the researchers in making chapter one Introduction and chapter two Literature Review, chapter three Research Methodology, chapter four Results and Discussions, chapter five Conclusion And Advice, and References and Research Report. By organizing workshop, the teachers could practice making Class Action Research (CAR). The workshops were conducted to make chapter one Introduction and chapter two Literature Review. The first workshop was sceduled in three meetings. Each meeting consisted of one cycle. Meeting 1 (Cycle 1): Researcher explained the material of Introduction and Literature Review. Then researcher gave several assignments by assigning teachers to make Chapter one. Meeting 2 (cycle 2): the researcher did feedback to know how far the teachers understands about the task of making Introduction and Literature Review. Meeting 3 (cycle 3): the researcher asked the teachers to make revisions. The revision was to fix what was not good about the Introduction and Literature Review.

Making chapter three Research Methodology was carried out on Workshop II (two) which consisted of three (3) meetings, each meeting consisted of one (1) cycle. Meeting 1 (Cycle 1): the researcher explained the material of Research Methodology. Then the researcher assigned the teachers to make chapter three. Meeting 2 (cycle 2): the researcher did feedback to know how far the understanding of the teachers about the task of making Research Methodology. Meeting 3 (cycle 3): the researcher asked the teacher to make revisions. The revision was to fix what was not good about Research Methodology. 
Chapter four Results And Discussions, chapter five Conclusion and Suggestion and References and Research Report were conducted in the Workshop III (three) which consisted of 3 meetings and each meeting consisted of one (1) cycle. Meeting 1 (Cycle 1): the researcher explained the material of chapter four, chapter five, references and research report. Then the researcher assigned the teachers to make chapter four, chapter five, references and research report. Meeting 2 (cycle 2): the researcher did feedback to know how far the teachers understand about the task of making chapter four, chapter five, references and research report. Meeting 2 (cycle 2): the researcher asked the teacher to make revisions. The revision was to fix what was not good about chapter four, chapter five, references and research report. Meeting 3 (cycle 3): researcher asked the teachers to make revisions. The revision was to fix what was not good about chapter four, chapter five, references and research report. This workshop is conducted to make chapter one Introduction and chapter two Literature Review consisted of 3 cycles. Cycle 1: Researchers explain the material chapter one Introduction and chapter two Literature Review assign teachers to make chapter one Introduction and chapter two Literature Review. Cycle 2: Feed back researchers to determine the extent of control of the teacher about the task of making chapter one Introduction and chapter two Literature Review. Cycle 3: Researchers tell the teacher to make revisions. The revision is to fix what is not good about the chapter one Introduction and chapter two Literature Review.

\section{METHODS}

The location of this research was carried out in SMP Negeri 30 Medan located at Jl. Bunga Raya Gg. Acid Beetle family in Medan. The Subjects of the research were teachers of SMP Negeri 30 Medan numbered in 14 (fourteen) members.

The object of research was the Classroom Action Research (CAR). To create a Class Action Research (CAR) was done through AFR Model Workshop.

The model used in this workshop was a Kemmis model which was designed by cycle process consisted of four phases of activities, namely: planning, action, observing, and reflection. Theses Phases kept recycling until the problem was resolved. The model can seen in Figure 1.

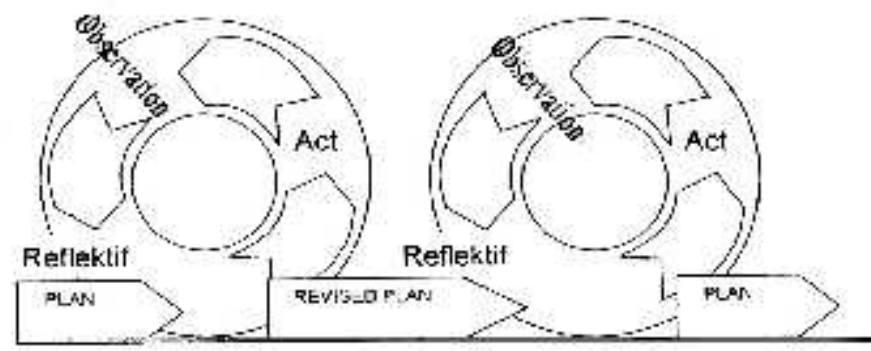

Fig 1. Cycle of Kemmis Model
There were two assignments of making this Classroom Action Research (CAR) at the workshop namely: (1) assessment of competence in creating a Class Action Research (CAR). This workshop was conducted to make chapter one Introduction and chapter two Literature Review consisted of 3 cycles The Workshop in cycle 1 (one) was meeting one assigning teachers to make chapter one Introduction and chapter two Literature Review consisted in 11 aspects with the number of scores 55. Then the maximum score is 55. While the score obtained depended on the number of answers of the five components. The score could be calculated using the following formula;

$$
\text { Value }=\frac{\text { scure ubtained }}{\text { smore max }} \times 100 \%
$$

The aspects of assessments making the CAR are : $1=$ The ability to make Title PTK

$2=$ The ability to create the background of problem

$3=$ The ability to make the identification of problem

$4=$ The ability to make the scope of problem

$5=$ the ability to make the Formulation of problem

$6=$ The ability to make the Objective of problem

$7=$ The ability to make the significance of Research

$8=$ The ability to make the Theoretical Study

$9=$ The ability to make the Relevant Result Findings

$10=$ The ability to make the conceptual frame work

$11=$ The ability to make a hypothesis of Actions

Value interval:

$\begin{array}{ll}86-100 & : \text { Very good } \\ 71-8 & : \text { Well } \\ 56-70 & : \text { Enough } \\ <56 & \text { : Less }\end{array}$

(2) assignment of the teacher attitudes in making class action research (CAR). The assignment of teacher attitudes in making classroom action research (CAR) consisted of four aspects, each aspect scored of 5 . Then the maximum score was 20. While the score of the acquisition depended on the number of answers of the five components. Values could be calculated using the following formula:

The aspects of assignment in teacher attitudes in making classroom action research (CAR):

a) Interesting to do

b) Easy to do

c) Excited

d) Motivated to make some action research (CAR)

\section{Score :}

$5=\mathrm{SA}=$ Strongly Agree

$4=\mathrm{A}=$ Agree

$3=$ LA $=$ Less Agree

$2=\mathrm{DA}=$ Disagree

$1=\mathrm{SDA}=$ Strongly Disagree 


\section{RESULT AND DISCUSSION}

Data from observation of teacher competence in making chapter one Introduction and chapter two Literature Review at the meeting of 1 to 3 of 14 (fourteen) teachers of SMP Negeri 30 Medan participating in the workshop are presented in Table 1 below:

TABLE I. TEACHER COMPETENCY DATA OF SMP NEGERI 30 MEDAN IN MAKING CHAPTER ONE INTRODUCTION AND CHAPTER TWO LITERATURE REVIEW CYCLE 1 MEETING (ASSIGNMENT)

\begin{tabular}{|l|c|c|}
\hline Sample & Score & Description \\
\hline Teacher 1 & 54.55 & Less \\
\hline Teacher 2 & 50.91 & Less \\
\hline Teacher 3 & 45.45 & Less \\
\hline Teacher 4 & 40.00 & Less \\
\hline Teacher 5 & 50.91 & Less \\
\hline Teacher 6 & 49.09 & Less \\
\hline Teacher 7 & 52.73 & Less \\
\hline Teacher 8 & 43.64 & Less \\
\hline Teacher 9 & 49.09 & Less \\
\hline Teacher 10 & 38.18 & Less \\
\hline Teacher 11 & 47.27 & Less \\
\hline Teacher 12 & 52.73 & Less \\
\hline Teacher 14 & 45.45 & Less \\
\hline Teacher 14 & 52.73 & Less \\
\hline Everage & $\mathbf{4 8 . 0 5}$ & Less \\
\hline
\end{tabular}

\section{Cycle 1 (Assignment)}

\section{Reflection Cycle 1}

During the implementation phase of reflection cycles, researchers together with the supervisor of school reflected on the results of observations of teacher competence in making chapter one Introduction and chapter two Literature Review by way of assignment assigned by the researcher. From 14 (fourteen) teachers of SMP Negeri 30 Medan participating in the workshop found that: (a) the ability to make title of CAR was $52.86 \%$ (less), (b) the ability to create a background of research was $42.86 \%$ (less), (c) the ability to make the Identification of Problems was 48.of CAR 21\% (less), (d) the ability to make the scope of problems was $58.03 \%$ (less), (e) the ability to make formulation of Problems was $48.21 \%$ (less), (f) the ability to make Objective of the research was $35.71 \%$ (less), (g) the ability to make the benefits of research was $41.43 \%$ (less), (h) the ability to make a Literature Review was $46.43 \%$ (less), (i) the ability to make findings of Relevant of Research was $41.43 \%$ (or less), (j) the ability to make the framework of the research was $48.21 \%$ (less), and (k) the ability to create a hypothesis of Action was $55.71 \%$ (less).

The average value of teachers' ability to make chapter one Introduction and chapter two Literature Review was 48.05 (approximately).

From the observation of teacher competence in making chapter one Introduction and chapter two Literature Review at the meeting 1 (Assignment), from 14 (fourteen) teachers of SMP Negeri 30 Medan in accordance with Table 4.1, eleven of the observed aspects can be concluded that 14 teachers of
SMP Negeri 30 Medan participanting in the workshop still lacked of the ability $(48.05 \%)$ in making chapter one Introduction and chapter two Literature Review.

\section{Cycle 2 (feedback)}

\section{a) Observation Results of Implementation Cycle}

The results of observations from this cycle 2, researchers together with school supervisors observed observations of teachers of SMP Negeri 30 Medan to make Chapter one Introduction and Chapter two Literature Review by Feed Back assigned by researchers and noted all the implementation of the making of Chapter one Introduction and Chapter two Literature Review.

Data from observations of teacher competencies made Chapter one Introduction and Chapter two Literature Review in cycle 2 (Feed Back) by 14 (fourteen) teachers of SMP Negeri 30 Medan parcipating in the workshops are prsented as in table 2 below:

TABLE II.

TEACHER COMPETENCY DATA OF SMP NEGERI 30 MEDAN IN MAKING CHAPTER ONE INTRODUCTION AND CHAPTER TWO LITERATURE REVIEW CYCLE 2 MEETING (FEED BACK

\begin{tabular}{|c|c|c|}
\hline Sample & Score & Description \\
\hline Teacher 1 & 72.73 & Good \\
\hline Teacher 2 & 67.27 & Enough \\
\hline Teacher 3 & 63.64 & Enough \\
\hline Teacher 4 & 60.00 & Enough \\
\hline Teacher 5 & 70.91 & Enough \\
\hline Teacher 6 & 69.09 & Enough \\
\hline Teacher 7 & 72.73 & Good \\
\hline Teacher 8 & 63.64 & Enough \\
\hline Teacher 9 & 69.09 & Enough \\
\hline Teacher 10 & 58.18 & Enough \\
\hline Teacher 11 & 67.27 & Enough \\
\hline Teacher 12 & 72.73 & Good \\
\hline Teacher 14 & 65.45 & Enough \\
\hline Teacher 14 & 72.73 & Good \\
\hline Everage & $\mathbf{6 7 . 6 0}$ & Enough \\
\hline
\end{tabular}

In the implementation phase of reflection cycle 2 of this workshop, researchers together with school supervisors reflected on the results of observations of teacher competencies making Chapter one Introduction, And Chapter two Literature Review by Feedback assigned by researchers, 14 (fourteen) teachers of SMP Negeri 30 were found that; (a) ability to make Title of CAR was $71.43 \%$ (good), (b) ability to make Background of Problem was 59.52\% (enough), (c) ability to make Problem Identification was $73.21 \%$ (good), (d) ability to make a Limitation of Problem was $69.64 \%$ (enough), (e) ability to make a Formulation of Problem was $73.21 \%$ (good), (f) ability to make a Objective of Research was $73.81 \%$ (enough), (g) ability to make Benefits of Research was $61.43 \%$ (enough), (h) ability to make literature review was $61.90 \%$ (enough), (i) ability to make Relevant Research Findings was $60.00 \%$ (enough), (j) ability to make Framework 
of research was $71.43 \%$ (good), and (k) ability to make the Hypothesis of Action was $74.29 \%$ (good)

The average value of the ability of teachers to make Chapter one Introduction, And Chapter two Literature Review was 67.60 (enough).From the observations of teacher competence Chapter one Introduction, And Chapter two Literature Review in cycle 2 (Feed Back), of 14 (fourteen) teachers of SMP Negeri 30 Medan in workshop participants according to table 4.2. it turns out that from the eleven observed aspects, it can be concluded that the teachers were still lacking of making Chapter one Introduction, And Chapter two Literature Review. The results of cycle one were compared with the results of cycle two, the teacher competency made Chapter one Introduction, And Chapter two Literature Review namely: (a) the ability to make Title of CAR was from $52.86 \%$ (less) became $71.43 \%$ (good), but still needed to be improved, (b) ability to make Background of Problem was $42.86 \%$ (less) became $59.52 \%$ (enough), but still needed to be improved, (c) ability to make Problem Identification was $48.21 \%$ (less) became $73.21 \%$ (good) but still needed to be improved, (d) the ability to create a Problem Limitation was $58.03 \%$ (less) became $69.64 \%$ (enough) but still needed to be improved, and (e) ability to make a formula of the Problem was $48.21 \%$ (less) became $73.21 \%$ (good) but still needs to be improved. f) ability to make Research Goals was $35.71 \%$ (less) became $73.81 \%$ (enough) but still needed to be improved. g) ability to make Research Benefits was $41.43 \%$ (less) became $61.43 \%$ enough) but still needed to be improved, h) ability to make Literature Review $=46.43 \%$ (less) became $61.90 \%$ (enough) but still needed to be improved, i) ability to make Relevant Research Findings was $41.43 \%$ (less), became $60.00 \%$ (enough) but still needed to be improved, j) ability to make a Framework was $48.21 \%$ (less ) became $71.43 \%$ (good) but still needs to be improved, and $\mathrm{k}$ ) the ability to make the Hypothesis of Action was $55.71 \%$ (less) became $74.29 \%$ (good) but still needed to be improved.

The average value of the ability of teachers to make Chapter one Introduction, And Chapter two Literature Review was 48.05 (less) became 67.60 (less) but still needed to be improved. This workshop is successful if (a) $75 \%$ of teachers are able to make Chapter one Introduction, And Chapter two Literature Review.

In accordance with the results of the reflection, the researcher decided that making the CAR did not meet the requirements, so it was necessary to proceed to cycle one of the third meeting to see the comparison of teacher competencies to make Chapter on Introduction, And Chapter two Literature Review compared to revision of making Chapter on Introduction, And Chapter two Literature Review.

Cycle 3 (Revision)

a) Observation Results of Cycle 3

In the implementation phase of the Cycle 3 of this workshop, the researcher guided the teachers to make Chapter one Introduction, And Chapter two Literature Review. by the way of Revision that provided input from the work done by all participants. The researcher asked each teacher to complete Chapter one Introduction, And Chapter two Literature Review., and be given the opportunity to school supervisors to comment on what was good and what the shortcomings of Chapter one Introduction, And Chapter two Literature Review made by the teachers. If there are still shortcomings of Chapter one Introduction, And Chapter two Literature Review, the researcher asks the teacher to refine it.

The results of observations of this cycle 3 , researchers together with school supervisors inspected observations of teachers of SMP Negeri 30 Medan to make Chapter one Introduction, And Chapter two Literature Review by way of Revision assigned by the researcher.

Data from observations of teacher competencies in making Chapter one Introduction, And Chapter two Literature Review in cycle 3 (Revised) are presented in the table 4 below;

TABLE III

TEACHER COMPETENCY DATA OF SMP NEGERI 30 MEDAN IN MAKING CHAPTER ONE INTRODUCTION AND CHAPTER TWO LITERATURE REVIEW CYCLE 3 MEETING (REVISI)

\begin{tabular}{|l|c|c|}
\hline Sample & Score & Description \\
\hline Teacher 1 & 96.36 & Very good \\
\hline Teacher 2 & 89.09 & Very good \\
\hline Teacher 3 & 85.45 & Good \\
\hline Teacher 4 & 83.64 & Good \\
\hline Teacher 5 & 90.91 & Very good \\
\hline Teacher 6 & 89.09 & Very good \\
\hline Teacher 7 & 96.36 & Very good \\
\hline Teacher 8 & 85.45 & Good \\
\hline Teacher 9 & 94.54 & Very good \\
\hline Teacher 10 & 78.18 & Good \\
\hline Teacher 11 & 87.27 & Very good \\
\hline Teacher 12 & 89.09 & Very good \\
\hline Teacher 14 & 85.45 & Good \\
\hline Teacher 14 & 90.91 & Very good \\
\hline Everage & $\mathbf{8 2 . 8 5}$ & Good \\
\hline
\end{tabular}

In the implementation phase of the reflection cycle 3 of this workshop, researchers together with school supervisors reflected on the observations of teacher competencies making Chapter one Introduction, And Chapter two Literature Review by way of Revision assigned by the researcher and found that; (a) ability to make Title of CAR was $92.86 \%$ (very good), (b) ability to make Background of Problem was $82.14 \%$ (good), (c) ability to make Problem Identification was $94.64 \%$ (very good), (d) ability to make a Problem Limitation was $83.93 \%$ (good), (e) ability to make a Problem Formulation was $96.43 \%$ (very good), (f) ability to make a Research Objective was $100.00 \%$ (very good), (g) ability to make Research Benefits was $87.14 \%$ (very good), (h) ability to make Literature Review was $80.95 \%$ (good), (i) ability to make Relevant Research Findings was $82,86 \%$ (good), (j) ability to make a Framework was $94.64 \%$ (very good), and (k) ability to make the Hypothesis of action was $94.29 \%$ (very good). 
The average value of the ability of teachers to make Chapter o Introduction, And Chapter two Literature Review was 67.60 (less) became 82.85 (good) it was completed. In accordance with the results of reflection which is at least $75 \%$, the researcher decided that making CAR has met these requirements, so there is no need to proceed to the fourth cycle.

The results of the questionnaire on teacher attitudes in making CAR from 14 teachers of SMP Negeri 30 Medan participating in the workshop were presented in the table 4 below:

TABLE IV. DATA OF TEACHER COMPETENCY IN MAKING CLASS ACTION RESEARCH THROUGH AFR MODEL WORKSHOP

\begin{tabular}{|c|c|c|}
\hline Cycle & Everage & Description \\
\hline 1. & 48.05 & Less \\
\hline 2. & 67.60 & Enough \\
\hline 3. & 82.85 & Good \\
\hline
\end{tabular}

\section{CONCLUSION}

Based on the results of the research, it can be concluded as follows; The results of the analysis of the data in making CAR namely Cycle 1 meeting 1 was 48.05. Cycle 1 meeting 2 was 67.60. Cycle 1 meeting 3 was 82.85 . The average of increase in teacher competency in cycle 1 was 34.802 . To be able to find out efforts to improve teacher competency in making Classroom Action Research (CAR), the AFR Model Workshop can be conducted by: a) Explanation of material from researchers as resource persons, b) Assignments, c) Feed Back, and d) Revisions.

\section{REFERENCES}

[1] G. Afnil. (2008). Association Permendiknas About Education Standards and Personnel, Jakarat: Publisher Asa Mandiri.J. Clerk Maxwell, A Treatise on Electricity and Magnetism, 3rd ed., vol. 2. Oxford: Clarendon, 1892, pp.68-73.

[2] I. Machali. (2011). Manajemen Mutu Sistem Pembelajaran Madrasah: Kontribusi Kepemimpinan Kepala Madrasah, Kompetensi Guru, Sarana Prasarana, dan Budaya Madrasah Terhadap Mutu Pembelajaran dan Dampaknya Terhadap Kepuasan Siswa di Madrasah Aliyah Swasta di Kota Yogyakarta Tahun 2009/2010 (Doctoral dissertation, Universitas Pendidikan Indonesia).

[3] P. D. Sukardi. (2003). Research Methodology and Practice Competency Education, Jakarta: Earth Literacy.

[4] I. A. Nurhasanah. (2016). Penerapan Metode Role Playing Untuk Meningkatkan Hasil Belajar Siswa Pada Materi Hubungan Mahluk Hidup Dengan Lingkungannya (Penelitian Tindakan Kelas di Kelas IV SDN Sindang II Kecamatan Sumedang Utara Kabupaten Sumedang) (Doctoral dissertation, Universitas Pendidikan Indonesia).

[5] S. Arikunto, Suhardjono and Supardi. (2007). Class Action Research, Jakarta: PT Earth Literacy.

[6] T. Sumini. (2017). Penelitian Tindakan Kelas dan Pengembangan Profesi Guru. Tersedia secara online di: https://www. usd. ac. $\mathrm{id} /$ lembaga/lppm/f113/Jurnal\% $\quad 20 \quad$ Historia\% 20Vitae/vol24nol april2010/Penelitian\% 20 Tindakan\% 20 Kelas\% $20 \mathrm{Th} \%$ 20sumini. pdf [diakses di Manado, Sulawesi Utara, Indonesia: 24 Agustus 2018].

[7] H. Suprijanto. (2007) Adult Education: From Theory to Application, Jakarta: PT. Earth Literacy.

[8] R. Resmita, Hayatunnufus, H., \& Yanita, M. (2017). Tinjauan Tentang Kelayakan Sarana dan Prasarana Workshop Program Keahlian Tata Kecantikan Rambut SMKN 7 Padang. E-Journal Home Economic and Tourism, 15(2)

[9] Z.D.Hisham. (2007). Active Learning Strategies, Yogyakarta: CTSD, IAIN Sunan Kalijaga.

[10] A. Wahyudi. (2016). Persepsi Guru tentang Pelaksanaan Workshop Kurikulum 2013 bagi Guru SD di Sekolah Piloting Kabupaten Sleman. Hanata Widya, 5(1). 